\title{
The Protective Effects of Borax on Doxorubicin Induced Cardiotoxicity in Rats
}

\author{
Burçin ÇELIKKEZEN ${ }^{1 *}$, Saadettin TANYILDIZI ${ }^{1}$, Gökan OTO ${ }^{2}$ \\ ${ }^{1}$ Firat University, Veterinary Science, Department of Pharmacology, Elâzı̆̆, Turkey \\ ${ }^{2}$ Van Yüzüncü Yll University, Faculty of Medicine, Department of Pharmacology, Van, Turkey. \\ (ORCID: 0000-0003-3097-9814) (ORCID: 0000-0001-7012-5392) (ORCID: 0000-0002-8492-4846)
}

\begin{abstract}
Boron and boron compounds have benefical effects on health of human and animals.This study was designed to determine the protective effect of borax (BX) in doxorubicin (DXR) induced cardiotoxicity in rats. In this study, 20 Wistar-Albino male rats* ${ }^{*}$ were used. The rats were divided into four groups including 5 rats in each one; control group (standard pellet food + water + normal saline), doxorubicin $(3.75 \mathrm{mg} / \mathrm{kg} / \mathrm{ip}$, single dose in a week), doxorubicin + borax $(3,75 \mathrm{mg} / \mathrm{kg} / \mathrm{ip}+25 \mathrm{mg} / \mathrm{kg} /$ oral/ respectively), and borax $(25 \mathrm{mg} / \mathrm{kg} /$ oral, single dose in a week). At the end of the experiment, to evaluate antioxidant activity MDA, GSH, CAT, SOD levels determined in blood samples of rats. Besides, CK levels were investigated to determine the effect of doxorubucine on heart tissue. According to the results, MDA levels increased significantly in doxorubucin induced group $(\mathrm{p}<0.05)$. After borax treatment MDA status decreased under the control values $(\mathrm{p}<0.05)$. GSH status decreased in all groups. While CAT level decreased in DXR induced group in a statistically important rate $(\mathrm{p}<0.05)$, it was observed near control values in BX and BX+DXR induced groups. SOD status indicated increase in BX and DXR groups. In addition, CK levels increased in all groups compared to the control. In the increases only in DXR induced group, significance was determined as $p<0.05$. As a result, these data indicated that borax may use to prevent cardiotoxic effect of doxorubicin.
\end{abstract}

Keywords: Borax, Boron Compounds, Doxorubicin, Cardiotoxicity, Rat

\section{Ratlarda Doksorubusin ile Teşvik edilmiş Kardiyotoksisite Üzerine Boraks'ın Koruyucu Etkileri}

\begin{abstract}
$\ddot{\mathbf{O} z}$
Doksorubusin (DXR) önemli bir antikanser ilaçtır ve oksidatif stres yoluyla kardiyotoksisiteye neden olur. Bor bileşiklerinin antioksidan özelliğe sahip olduğu literatürde bildirilmiştir. Bu çalışma, boraksın (BX) sıçanlarda DXR ile indüklenen kardiyotoksisitede koruyucu etkisini ilk kez belirlemek için tasarlanmıştır. Bu çalı̧̧mada, 20 adet Wistar-Albino erkek sıçan kullanıldı. Siçanlar, her biri 5 sıçan olmak üzere dört gruba ayrıldı; kontrol grubu (standart pelet yem + su + serum fizyolojik), doksorubisin (3,75 mg / kg / ip, haftada tek doz), DXR + BX (3,75 $\mathrm{mg} / \mathrm{kg} / \mathrm{ip}+25 \mathrm{mg} / \mathrm{kg} /$ oral / sırasıyla $)$ ve BX $(25 \mathrm{mg} / \mathrm{kg} /$ oral, haftada tek doz). Çalışma sonunda antioksidan aktiviteyi değerlendirmek için MDA, GSH, CAT, SOD seviyeleri belirlendi. Ayrıca DXR'nin kalp dokusu üzerindeki etkisini belirlemek için kreatin kinaz (CK) seviyeleri araştırıldı. Elde edilen sonuçlara göre, MDA düzeyleri doksorubusin uygulanan grupta anlamlı olarak arttı $(\mathrm{p}<0.05)$. Boraks tedavisi sonrası MDA durumu kontrol değerlerinin altına düştü $(\mathrm{p}<0.05)$. CAT düzeyi DXR uygulanan grupta istatistiksel olarak önemli oranda düsserken $(\mathrm{p}<0.05)$, $\mathrm{BX}$ ve $\mathrm{BX}+\mathrm{DXR}$ uygulanan gruplarda kontrol değerlerine yakın gözlendi. SOD düzeyleri, BX ve DXR gruplarında artış gösterdi. Sonuç olarak, bu veriler BX'in DXR'nin kardiyotoksik etkisini önlemek için kullanabileceğini gösterdi.
\end{abstract}

Anahtar kelimeler: Boraks, Bor bileşikleri, Doksorubisin, Kardiyotoksisite, Rat

"Corresponding author: burcinozer44@gmail.com

Received: 09.03.2021, Accepted: 03.06.2021 


\section{Introduction}

Doxorubicin (DXR) is an anthracycline derivative drug which is extracted from culture of Streptomyces peucetius variete caesiu [1]. DXR is clinically used in treatments of leukemia, lymphoma, soft tissue and bone sarcomas, Wilms tumor, neuroblastoma, and hepatoblastoma [2,3]. However, cardiotoxicity is the most important toxic effect stated and is the most critical factor which commonly restricts the use of the drug. The mechanism of cardiotoxicity developing based on the use of DXR has not been understood yet and several theories have been suggested on this issue [4]. The mechanism, which seems to be the most significant and possible one, is established on stimulation of apoptosis in cardiomyocytes and inducing oxidative stress in heart muscle via DXR [5]. Because antioxidant capacity of cardiac myocytes is inadequate to be protected against reactive oxygen species leading to mitochondrial damage and lipid peroxidation [6].

Oxidative stress (OS) is originate from imbalance between production and accumulation of reactive oxygen species in cells and tissues [7]. OS damages cell membranes, lipoproteins, DNA, promote apoptosis resulting in aging, cancer, cardiovascular diseases and other diseases [8-10]. On the other hand, many studies stated that natural products rich in antioxidants have an important role in the protection of cardiotoxicity of DXR [11]. The protective mechanism of natural products against DXR induced cardiotoxicity is uncertain. However, reports have exhibited that the mechanism may be releated with inhibition of harmful cardivascular effects of the metabolic syndrome or inhibition of reactive oxygen species generation [12-14]. Antioxidants have attracted great attention as they play a protective role in different complications along with oxidative stress. The beneficial effects of antioxidants on DXR-induced cardiotoxicity have been demonstrated in previous studies. Therefore, it has been reported that combinatorial treatment with DXR and antioxidants recommended to suppress the cardiotoxicity [15-17].

Boron is a natural element commonly found on earth and combines with oxygen to form borates $[18,19]$. Borax $(\mathrm{BX})$, is an important commercial boron compound and there are a lot of report suggesting biological effects and benefical therapeutic properties of BX including antioxidative [20], antimutagenic [21], and anti-inflammatory [22]. As far as we know, there is no study about the protective affects of BX on DXR induced cardiotoxicity. The goal of this work is to determine the affects of BX on oxidative stress and levels of creatin kinase (CK) in DXR induced rats.

\section{Material and Methods}

In this work, 20 Wistar Albino male rats, having a live weight of 180-200 $\mathrm{g}$ and being eight weeks old, were used. The rats were supplied from Van Yüzüncü Y1l University (YYU) rat production unit and kept waiting for 7 days to ensure adaptation to environment before the experiment. The rats were fed with pellet food and water ad libitum during adaptation period. Experimental protocol of the study was approved by the Committee on the Ethics of Animal Experiments at YYU (26.03.2014 Desicion no: 2014/04).

The rats to be included in the experiment were divided into 4 groups, including 5 rats in each one.

Group 1: Control group (standard pellet food + water+ physiological saline solution), administered for 4 weeks.

Group 2: Doxorubicin $(3.75 \mathrm{mg} / \mathrm{kg} / \mathrm{ip}$, once a week, administered for 4 weeks at total dose of $15 \mathrm{mg} / \mathrm{kg}$ ) [23].

Group 3: Doxorubicin + Borax $(3,75 \mathrm{mg} / \mathrm{kg} / \mathrm{ip}$, once a week, administered for 4 weeks at total dose of $15 \mathrm{mg} / \mathrm{kg}$; Borax of $25 \mathrm{mg} / \mathrm{kg} /$ week dose was administered via oral route for 4 weeks at total dose of $100 \mathrm{mg} / \mathrm{kg}$ ).

Group 4: Borax of $25 \mathrm{mg} / \mathrm{kg} /$ week dose was administered via oral route for 4 weeks at total dose of $100 \mathrm{mg} / \mathrm{kg}$ [24]

Blood was drawn from the heart of all of the animals in the study by anaesthetizing them with ketamine and then they were sacrificed. MDA, GSH, SOD, CAT, and CK levels in blood samples were studied by using the following methods. 


\subsection{Reduced Glutathione (GSH) Assay}

Blood samples containing EDTA were mixed with distilled water. All proteins without sulfhydryl (SH) were precipitated by using precipitation solution. Glutathione level in the samples was measured by reading the absorbances at $412 \mathrm{~nm}$ wavelength in Perkin Elmer UV/Vis Spectrophotometer within 24 hours [25,26]. Distilled water of $1.8 \mathrm{ml}$ was added into $200 \mu \mathrm{l}$ of blood samples (with EDTA) to induce hemolysis. Precipitation reagent of $3 \mathrm{ml}$ was added into hemolysate. After waiting for 5 minutes, the mixture was infiltrated using filter paper and $2 \mathrm{ml}$ of the resultant supernatant was transferred into different test tubes. $8 \mathrm{ml}$ phosphate solution and $1 \mathrm{ml}$ of DTNB solution were added. For the blank solution, $2 \mathrm{ml}$ precipitation solution (3 volumes of precipitation reagent +2 volumes of distilled water), $8 \mathrm{ml}$ phosphate solution, and $1 \mathrm{ml}$ of DTNB solution were used. As the standard, $40 \mathrm{mg}$ of GSH standard was prepared with distilled water. Absorbances of standard samples versus blank were identified at 412 $\mathrm{nm}$ (Perkin Elmer UV/Vis) and the results were calculated in $\mathrm{mg} / \mathrm{dl}$ whole blood.

\subsection{Malondialdehyde (MDA) Assay}

Malondialdehyde, an important product of lipid peroxidation, is measured spectrophotometrically based on the formation of colored products by TBA [27,28]. $800 \mu \mathrm{l}$ of phosphate buffer and $25 \mu \mathrm{l}$ of BHT solution, and $500 \mu \mathrm{l}$ of $30 \%$ TCA were added into test tube containing $200 \mu \mathrm{l}$ of the whole blood. Tubes were mixed at $2000 \mathrm{rpm}$ and cooled in ice at $-20 \mathrm{C}^{\circ}$ for 2 hours. After centrifuging the samples at 2000 rpm for 15 minutes, $1 \mathrm{ml}$ of supernatants was transferred into different tubes and $75 \mu \mathrm{l}$ of EDTA and $250 \mu \mathrm{l}$ of TBA solution were added. Tubes were mixed and were kept in hot water bath $\left(\right.$ at $90 \mathrm{C}^{\circ}$ ) for 15 minutes. At room temperature, absorbances were read at 532 and $600 \mathrm{~nm}$ (Perkin Elmer UV/Vis). MDA levels of hemoglobin were calculated by subtracting optical densities at $600 \mathrm{~nm}$ from one read at $532 \mathrm{~nm}$ in examination on erythrocytes.

\subsection{CAT Assay}

CAT assay was performed via Cayman Catalase Assay Kit (Item No: 707002). Briefly, diluted assay buffer $(100 \mu \mathrm{l})$, methanol $(30 \mu \mathrm{l})$ and sample $(20 \mu \mathrm{l})$ were put into two tubes. Diluted $\mathrm{H}_{2} \mathrm{O}_{2}(20 \mu \mathrm{l})$ put into all the tubes to start reactions and incubated via a shaker for 20 minutes at room temperature. Then, catalase purphald (chromagen) $(30 \mu \mathrm{l})$ and diluted $\mathrm{KOH}(30 \mu \mathrm{l})$ were added into each tube to end the reaction. It was incubated via a shaker at room temperature for 10 minutes again. At the end of the experiment, catalase potassium periodate $(10 \mu \mathrm{l})$ was added into each well and incubated for five minutes in a shaker at room temperature. The absorbance was detected at $540 \mathrm{~nm}$ via the plate reader (Bio-Tek, USA). In the experiment, positive control was prepared by adding diluted assay buffer (100 $\mu \mathrm{l})$, methanol $(30 \mu \mathrm{l})$, and catalase (control/20 $\mu \mathrm{l})$ in two tubes.

\subsection{SOD Assay}

SOD status were eveluated by using Cayman SOD Assay Kit (Serial No: 706002). Briefly, the diluted radical detector $(200 \mu \mathrm{l})$ and SOD standard $(10 \mu \mathrm{l})$ were added on the plate for standard tubes. For sample tubes, diluted radical detector $(200 \mu \mathrm{l})$ and sample $(10 \mu \mathrm{l})$ were added. Diluted xanthine oxidase $(20 \mu 1)$ was added into all the tubes to initiate the reactions and shaken for several minutes. After this step, the plate was incubated for 30 minutes in the shaker at room temperature. At the end of the experiment, absorbances were read at 440-460 nm via plate reader (Bio-Tek, USA).

\subsection{CK Assay}

CK analysis was performed using an autoanalyzer and a commercial kit. (Mindray BS- $800 \mathrm{M}$, Shenzhen, China). 


\subsection{Statistical Analysis}

Statistical analysis of this work was carried out with ANOVA test via IBM SPSS Statistics Version 20 packaged software.

\section{Results and Discussion}

DXR, an anthracycline derivative drug, is a commonly used anticancer agent [29]. DXR, which is used in chemotherapy and a free radical producer, may also lead to chromosomal injuries by elevating lipid peroxidation (LPO) [30]. In the literature, there are numerous studies investigating protective effects of antioxidants against anticancer drugs such as DXR yielding oxidative product $[31,32]$.

Furthermore, boron and boron compounds are reported to support antioxidant defense system of tissues in animal organisms by affecting oxidative metabolism via a mechanism which has not known yet [33-36]. In a study, zinc borate was stated to support antioxidant capacity and not to cause oxidative stress [37]. In another study, it was reported that antioxidant defense system was strengthened in rats administered with BX via oral route [38].

As is known, elevated reactive oxygen species leads to increase of LPO and thus increase of MDA levels. Free radicals influence the important cellular structures such as lipid, protein, carbohydrate in the cell structure. Lipid peroxides form reactive carbon compounds by degrading rapidly. One of the important resultant structures is MDA and the increase of MDA is accepted to be a physiologically crucial indicator of oxidative stress [39-40].

In a study, it was determined that MDA levels of rats administered with $100 \mathrm{mg} / \mathrm{kg}$ borax showed a statistically important decrease according to the control [24]. Another study revealed that in rats administered with different levels of boric acid, MDA levels of the group fed with diet containing $40 \mathrm{mg}$ boric acid decreased compared to control group [41]. Recently, it was reported that MDA status indicated a statistically important decrease $(p<0.05)$ in lithium metaborate dihydrate induced group according to the control [42]. An in vitro study, it was determined that MDA levels of human blood cultures which were administered with $15 \mu \mathrm{mol}$ ulexite decreased according to the control, but decline was not statistically important [43]. When the data obtained from the present study were evaluated, it was found that MDA levels showed a statistically significant increase in the DXR-administered group compared to control group $(\mathrm{p}<0.05)$ as shown in Figure 1. In BX group, MDA level was determined to show a statistically important decrease $(\mathrm{p}<0.05)$. In addition, MDA levels of DXR+BX group were found to be lower than DXR group and this was in parallel with the previous studies.

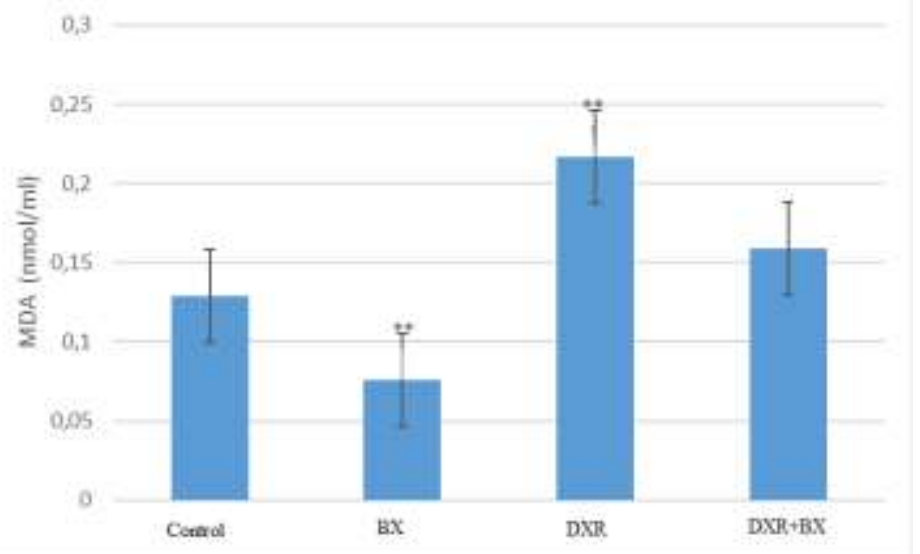

Figure 1. MDA levels of control, BX, DXR, and DXR+BX groups $\left({ }^{* *} \mathrm{p}<0.05\right)$.

GSH is a cellular tripeptide playing a vital role in protecting oxidant/antioxidant balance of tissues and is essential for normal cellular activities. This tripeptide eliminates the effects of peroxides and hydroperoxides resulting from oxidative stress [38]. It was identified in a previous study that GSHPx levels of rats administered with 40,80 , and $160 \mathrm{mg} / \mathrm{L}$ of boric acid showed decrease at rates of $12 \%$, $13.3 \%$, and $16.4 \%$, respectively [41]. In another study, it was determined that 50 and $500 \mathrm{mg} / \mathrm{L}$ doses of borax, boric acid, and ulexite significantly decreased GSH-Px levels of human blood cultures, 
decreases occurring in total GSH level were statistically significant at $500 \mathrm{mg} / \mathrm{L}$ of dose, and was not statistically significant at $50 \mathrm{mg} / \mathrm{L}$ of dose [43]. Recently, it was stated that GSH status indicated a statistically important decrease $(\mathrm{p}<0.05)$ in lithium metaborate dihydrate induced group according to the control [42]. As the results obtained from the present study were examined; GSH levels of all groups showed a statistically significant decrease compared to control group (Figure 2). Decreases recorded were not statistically significant. The obtained data were convenient with the previous studies. On the other hand, differently from the results obtained from the present study, GSH levels in erythrocytes of rats administered with boric acid and borax elevated compared to control group in another study [24]. The reason of this difference may have been associated with the fact that the breeds of experimental animals and methods of measurements used were different.

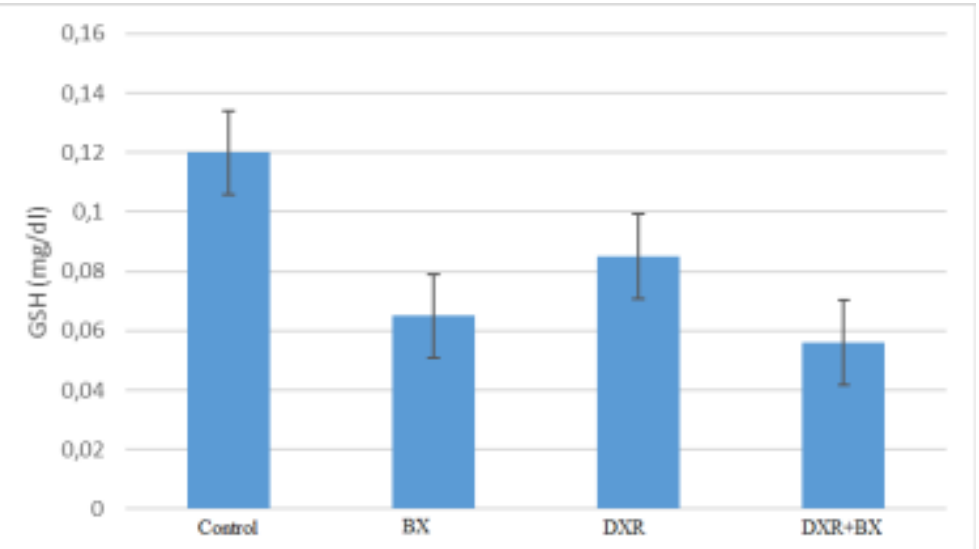

Figure 2. GSH levels of control, control, BX, DXR, and DXR+BX groups

Because oxidative stress occurs due decreased antioxidant levels [44], cellular levels of antioxidant enzymes (SOD, CAT, GSH-Px, GST, GR, and G-6-PDH) are reported to be crucial in cellular defense system [45]. SOD from these enzymes is noted to play the major role in defense against oxidative stress and to catalyze the reaction that transforms superoxide radical into hydrogen peroxide and oxygen [46]. Studies stated that antioxidant enzymes have an important role in preventing the damage led by reactive oxygen species and these enzymes were induced or inhibited in blood cells exposed to various toxic factors $[47,48]$. In a previous study, appropriate amount of boron intake inhibited ROS formation in leucocytes of lungs and 2'-deoxyribonucleoside cyanoboron which is a synthetic boron compound was reported to inhibit 5'-lipoxygenase activity in leucocyte and occurrence of free radical formation in fenton reaction [49]. Recently, it was determined that SOD levels increased in rats administered with different levels of boric acid (40,160,320, and $640 \mathrm{mg} / \mathrm{L})$ [41]. Another study revealed that SOD levels elevated in erythrocytes of rats administered with $100 \mathrm{mg} / \mathrm{kg}$ of boron as the protector against LPO induced by arsenic treatment compared to control group [50]. SOD levels of groups administered with BX and DXR alone in the present study were determined to increase according to control group (Figure 3). These increases were not statistically important. In the group administered with DXR + BX, SOD levels were lower only than the DXR group. The results obtained from the present study were determined to be in parallel with the previous studies and it was stated that BX supported antioxidant activity based on increased SOD activity. Despite biochemical function of boron has not been known completely yet, it was reported to be capable of acting as an indirect proton donor causing a specific effect on membrane structure and function [51]. Accordingly, it was reported that boron compounds (boric acid and borax) were likely to influence oxidative phosphoylation metabolism in mitochondria by increasing cAMP levels and to inhibit hydrolytic enzyme activities [52]. Besides, increased cAMP levels were stated to elevate antioxidant enzyme activities [53]. In the present study, borax may increase SOD activity by supporting accumulation of cAMP. On the other hand, differently from the results obtained, SOD activities were reported to show statistically insignificant decreases in rats administered with borax and boric acid compared to control group [24]. This difference may have been associated with the fact that the methods used for identifying SOD levels were different as well as different breeds of experimental animals. 


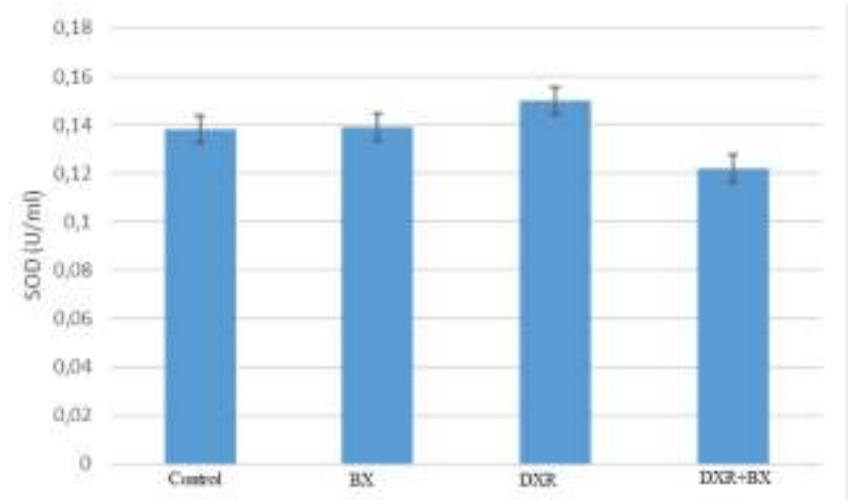

Figure 3. SOD levels of control, control, BX, DXR, and DXR+BX groups

Catalase (CAT) is an enzyme localized in peroxisomes [54]. CAT is an important oxidoreductase which converts $\mathrm{H}_{2} \mathrm{O}_{2}$ molecules into water and oxygen [55,56]. Mammalian catalases are homotetramers typically bonding 4 Fe-protoporphyrin IX (heme) or 4 NADPH molecule [57]. A previous study indicated that CAT levels in liver, kidney, and heart tissues and erythrocytes of rats administered with $100 \mathrm{mg}$ of borax declined compared to control group [24]. On the other hand, the effects of boric acid added into diet on CAT activity varied based on tissues of animals. CAT activity in erythrocytes of rats and rabbits decreased [58,59] but elevated in their livers [38]. In another study, doses of $100 \mathrm{mg} / \mathrm{L}$ of boric acid and $80 \mathrm{mg} / \mathrm{L}$ of borax were reported to have a negative effect on CAT levels $(\mathrm{P}<0.1)(60)$. In the present study, CAT levels were identified to decrease in the groups administered with BX and DXR alone, compared to control group as shown in Figure 4. While the decreases in BX group were not statistically significant, the decreases in the DXR group were statistically important $(\mathrm{p}<$ 0.05). CAT levels increased in DXR + BX group according to the control, however this increase not statistically important, and the results were compatible with the previous studies.

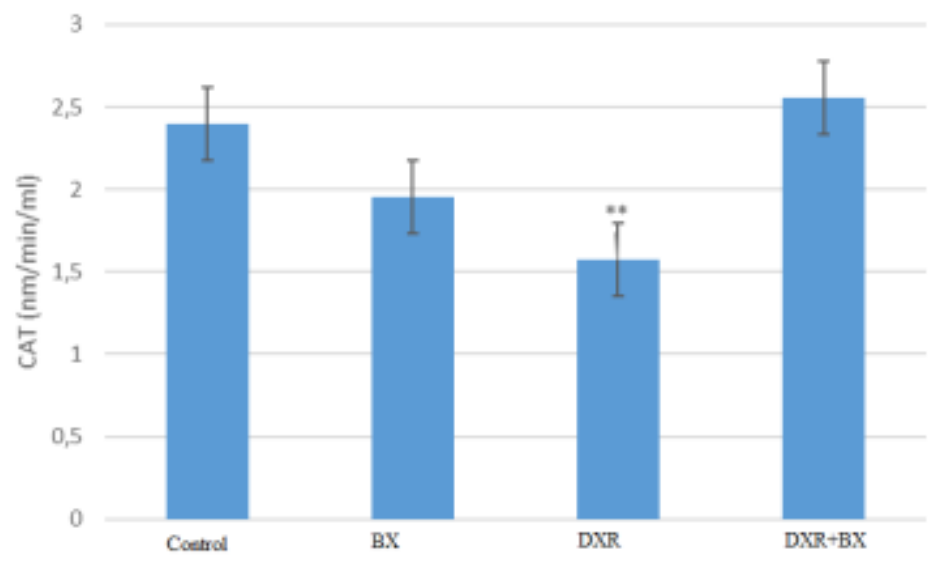

Figure 4. CAT levels of control, control, BX, DXR, and DXR+BX groups $\left({ }^{* *} \mathrm{p}<0.05\right)$.

On the other hand, it is reported that selenium, copper, and zinc are the cofactors of antioxidant enzymes and increasing concentrations of these elements may cause inhibition of CAT, SOD, and GSHPx activities in cells [51,61]. Boron can interact with these elements as well as trace elements [62]. In this sense, decreased CAT and GSH levels might be associated with the interactions occurring between boron compound and cofactors of the mentioned enzymes. On the other hand, differently from the results obtained, 5,10 and $20 \mathrm{mg} / \mathrm{kg}$ doses of boron were administered respectively as protector to rats treated with cyclophosphamide which leads to formation of free oxygen radicals and is used for chemotherapy in a recent study conducted on rats and it was determined that CAT activities of erythrocytes increased at all doses compared to control group [63]. The reason of this difference might be resulted from the use of elemental boron in the study and lower doses administered.

Creatine kinase (CK) is an important intracellular enzyme found in muscle cells (especially in skeletal muscle and myocardium) [64]. Generally, CK is the biomarker of acute myocardial infarction 
and CK activity or concentration is also used for verification of some other diseases in the modern clinic diagnoses. CK level rapidly elevates in the blood immediately after acute myocardial infarction and may be found at abnormal levels within 4-6 hours. The maximum CK level in humans is observed 18-24 hours after acute myocardial infarction [65]. In a study conducted on broilers, $500-750-1000 \mathrm{mg} / \mathrm{kg}$ doses of boric acid were added into their daily diets and CK levels increased at all doses compared to control group [66]. In a rat study, $1500 \mu \mathrm{g} / \mathrm{ml}$ of sodium borate was administered intravenously and CK levels increased [67]. When the results of the present study were examined; it was found that CK levels increased in all groups compared to control group as shown in Figure 5. and the results were in parallel with the previous studies. Even though the increases in DXR group were statistically significant $(\mathrm{p}<0.05)$, the increase in DXR + BX group was lower compared to the DXR group.

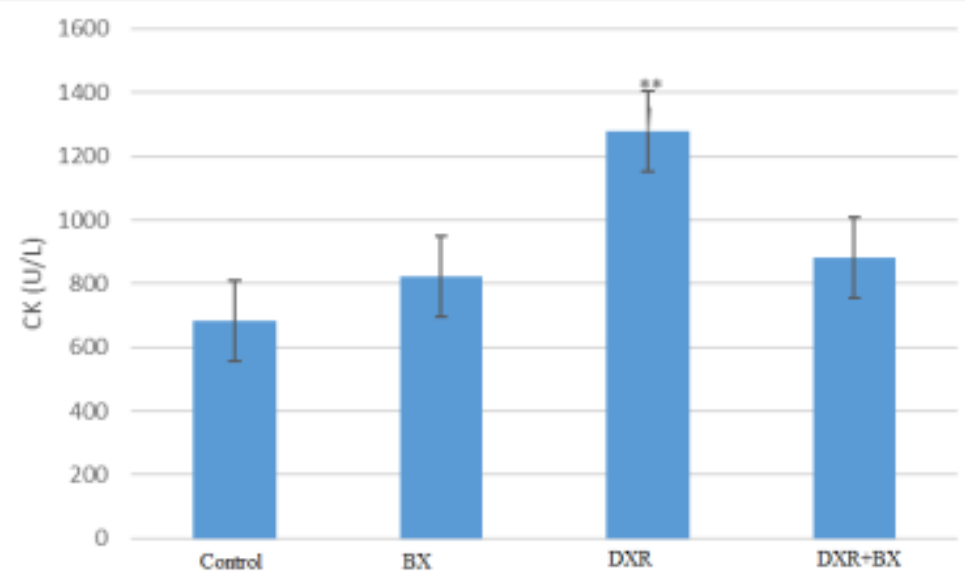

Figure 5. CK levels of control, BX, DXR, and DXR+BX groups $\left({ }^{* *} \mathrm{p}<0.05\right)$.

Consequently, administered dose of BX $(100 \mathrm{mg} / \mathrm{kg})$ was determined to increase antioxidant capacity by elevating SOD level and decreasing MDA levels in DXR induced cardiotoxicity. Besides, while CAT levels decreased and CK levels increased in all groups. Based on the results, it was concluded that BX may be beneficial for preventing cardiotoxicity which develops as the adverse effect of DXR.

\section{Author's Contributions}

Burçin ÇELIKEZEN and Sadettin TANYILDIZI contributed to the planning of the study, literature review, writing, the care of experimental animals and drug applications, experimental studies and interpretation of the results, while Gökhan OTO contributed to the application of drugs to the experimental animals, experimental studies and interpretation of the results. This article is summarized from Burçin ÇELIKEZEN's Master's thesis of the same name.

\section{Statement of Conflicts of Interest}

There is no conflict of interest among the authors.

\section{Statement of Research and Publication Ethics}

The authors declare that this study complies with Research and Publication Ethics.

\section{References}

[1] Baker S.D., Pharm D. 1997. Drug interaction with the taxanes. Pharmacotherapy, 17: 126-132.

[2] Muggia F.M., Green M.D. 1991. New anthracycline antitumor antibiotics. Critical Reviews oncology/ Hematology, 11: 43-64. 
[3] Hideg K., Kálai T. 2007. Novel antioxidants in anthracycline cardiotoxicity. Cardiovascular Toxicology, 7: 160-164.

[4] Ferrans V.J. 1983. Anthracycline cardiotoxicity. Advances in Experimental Medicine and Biology, 161: 519-532.

[5] Childs A.C., Phaneuf S.L., Dirks A.J., Phillips T., Leeuweburgh C. 2002. Doxorubicin treatment in vivo causes cytochrome $\mathrm{C}$ release and cardiomyocyte apoptosis, as well as increased mitochondrial efficiency, superoxide dismutase activity and Bcl2. Cancer Research, 62: 45924598.

[6] Menna P., Salvatorelli E., Minotti G. 2008. Cardiotoxicity of antitumor drugs. Chemical Research in Toxicology, 21: 978-989.

[7] Pizzino G., Irrera N., Cucinotta M., Pallio G., Mannino F., Arcoraci V., Squadrito F., Altavilla D., Bitto A. 2017. Oxidative stress: harms and benefits for human health. Oxidative Medicine and Cellular Longevity, 8416763. doi: 10.1155/2017/8416763

[8] Zhang H., Davies K.J.A., Forman H.J. 2015. Oxidative stress response and Nrf2 signaling in aging. Free Radical Biology and Medicine, 88: 314-336.

[9] El-Kenawi A., Ruffel B. 2017. Inflamattion, ROS, and mutagenesis. Cancer Cell, 32: 727-729.

[10] Ren J. 2007. Influence of gender on oxidative stress, lipid peroxidation, protein damage and apoptosis in hearts and brains from spontaneously hypertensive rats. Clinical and Experimental Pharmacology and Physiology, 34: 432-438.

[11] Hosseini A., Bakhtiari E., Mousavi S.H. 2017. Protective effect of hibiscus sabdariffa on doxorubicin-induced cytotoxicity in $\mathrm{H} 9 \mathrm{c} 2$ cardiomyoblast cells. Iranian Journal of Pharmaceutical Research, 16: 708-713.

[12] Capasso I., Esposito E., Maurea N., Montella M., Crispo A., De Laurentiis M., D'Aiuto M., Frasci G., Botti G., Grimaldi M., Cavalcanti E., Esposito G., Fucito A., Brillante G., D'Aiuto G., Ciliberto G. 2013. Combination of inositol and alpha lipoic acid in metabolic syndrome-affected women: a randomized placebo-controlled trial. Trials, 14 (1): 273

[13] Møller P., Loft S., Lundby C., Olsen N.V. 2001. Acute hypoxia and hypoxic exercise induce DNA strand breaks and oxidative DNA damage in humans. The FASEB Journal, 15 (7): 1181-1186.

[14] Nakamura K., Fushimi K., Kouchi H., Mihara K., Masahiro M, Ohe T., Namba M.1998. Inhibitory effects of antioxidants on neonatal rat cardiac myocyte hypertrophy induced by tumor necrosis factor-alpha and angiotensin II. Circulation, 98 (8): 794-799.

[15] Abdel-Daim M.M., Kilany O.E., Khalifa H.A., Ahmed A.A.M. 2017. Allicin ameliorates doxorubicin-induced cardiotoxicity in rats via suppression of oxidative stress, inflammation and apoptosis. Cancer Chemotherapy and Pharmacology, 80: 745-753

[16] Bishop S., Liu S.J. 2017. Cardioprotective action of the aqueous extract of Terminalia arjuna bark against toxicity induced by doxorubicin. Phytomedicine, 36:210-216.

[17] He H., Luo Y., Qiao Y., Zhang Z., Yin D., Yao J., You J., He M. 2018. Curcumin attenuates doxorubicin-induced cardiotoxicity via suppressing oxidative stress and preventing mitochondrial dysfunction mediated by 14- 3-3c. Food Function, 9: 4404-4418.

[18] Argust P. 1998. Distribution of boron in the environment. Biological Trace Element Research, 66:131-143

[19] Turkez H., Geyikoglu F., Mokhtar Y.I., Togar B. 2012. Eicosapentaenoic acid protects against 2,3,7,8-tetrachlorodibenzo-p-dioxin- induced hepatic toxicity in cultured rat hepatocytes. Cytotechnology, 64:15-25.

[20] Turkez H., Geyikoglu F., Tatar A., Keles S., Ozkan A. 2007. Effects of some boron compounds on peripheral human blood. Z Naturforsch C, 62: 889-896.

[21] Turkez H., Geyikoğlu F., Dirican E., Tatar A. 2012. In vitro studies on chemoprotective effect of borax against aflatoxin B1-induced genetic damage in human lymphocytes. Cytotechnology, 64 (6): 607-612.

[22] Routray I., Ali S. 2016. Boron induces lymphocyte proliferation and modulates the priming effects of lipopolysaccharide on macrophages. PLoS One 11: e0150607.

[23] Demirkaya E.1., Avci A., Kesik V., Karslioglu Y., Oztas E., Kismet E., Gokcay E., Durak I., Koseoglu V. 2009. Cardioprotective roles of aged garlic extract, grape seed proanthocyanidin, and hazelnut on doxorubicin-induced cardiotoxicity. Canadian Journal of Physiology and Pharmacology, 87: 633-640. 
[24] Ince S., Kucukkurt I., Cigerci I.H., Fidan A.F., Eryavuz A. 2010. The effects of dietary boric acid and borax supplementation on lipid peroxidation, antioxidant activity, and DNA damage in rats. Journal of Trace Elements in Medicine and Biology, 24: 161-164.

[25] Beutler E., Dubon O., Kelly B.M. 1963. Improved method for the determination of blood glutathione. Journal of Laboratory and Clinical Medicine, 61: 882-888.

[26] Rizzi R., Caroli A., Bolla P., Acciailoi A., Pagnacco G. 1998. Variability of reduced glutathione levels in Massese ewes and its effect on daily milk production. Journal of of Dairy Research, 55: 345-353.

[27] Gutteridge J.M. 1995. Lipit peroxidation and antioxidants as biomarkers of tissue damage. Clinical Chemistry, 41: 1819-1828.

[28] Sushil J.K., Mcuie R., Duett J., Herbest J.J.1989. Erythrocyte membrane lipid peroxidation and glycosylated hemoglobin in diabetes. Diabetes, 38: 1539-1543.

[29] Weiss R.B. 1992. The anthracyclines: will we ever find a better doxorubicin? Seminars in Oncology, 19: 670-686.

[30] Antunes L.M.G., Takahashi C.S. 1998. Effects of high doses of vitamins C and E against doxorubicine-induced chromosal damage in wistar rat bone marrow cells. Mutation Research, 419: 137-143.

[31] Antunes L.M.G., Arajuo M.C., Darin J.D.C., Bianchi M.L.P. 2000. Effects of antioxidants curcium and vitamin $\mathrm{C}$ on cisplatin-induced clastogenesis in wistar rat bone marrow cells. Mutation Research, 464: 131-137.

[32] Nefic H. 2001. Anticlastogenic effect of Vitamin C on cisplatin induced chromosome aberrations in human lymphocyte cultures. Mutation Research, 498: 89-98.

[33] Çelikezen F.Ç., Türkez H., Aydın E. 2015. The antioxidant and genotoxic activities of $\mathrm{Na}_{2} \mathrm{~B}_{4} \mathrm{O}_{7} .10 \mathrm{H}_{2} \mathrm{O}$ in vitro. Fresenius Environmental Bulletin, 24: 947-953.

[34] Çelikezen F.Ç., Toğar B., Özgeriş F.B., İzgi M.S., Türkez H. 2016. Cytogenetic and oxidative alterations after exposure of cultured human whole blood cells to lithium metaborate dehydrate. Cytotechnology. 68 (4): 821-827.

[35] Çelikezen F.Ç., Türkez H., Toğar B, İzgi M.S. 2014. DNA damaging and biochemical effects of potassium tetraborate. Experimental and Clinical Science, 13: 446-450.

[36] Kelly G.S. 1997. Boron: a review of its nutritional interactions and therapeutic uses. Alternative Medicine Review, 2: 48-56.

[37] Çelikezen F.Ç., Türkez H., Togar B. 2014. In vitro assessment of genotoxic and oxidative effects of zinc borate. Toxicological and Environmental Chemistry, 96: 777-782.

[38] Pawa S., Ali S. 2006. Boron Ameliorates Fulminant Hepatic Failure by Counteracting the Changes Associated with the Oxidative Stress. Chemico-Biological Interactions, 160: 89-98.

[39] Kim H.1., Oh E., Im H., Mun J., Yang M., Khim J.Y., Lee E., Lim S.H., Kong M.H., Lee M., Sul D. 2006. Oxidative damages in the DNA, lipids, and proteins of rats exposed to isofluranes and alcohols. Toxicology, 220: 169-178.

[40] Siu F.K., Lo S.C., Leung M.C. 2004. Effectiveness of multiple pre-ischemia electro-acupuncture on attenuating lipid peroxidation induced by cerebral ischemia in adult rats. Life Science, 75: 1323-1332.

[41] Hu Q.1., Li S., Qiao E. Tang Z., Jin E., Jin G., Gu Y. 2014. Effects of boron on structure and antioksidative activities of spleen in rats. Biological Trace Element Research, 158: 73-80.

[42] Taşdemir M., Çelikezen F.Ç., Oto G., Özbey F. 2020. The effects of pretreatment with lithium metaborate dihydrate on lipid peroxidation and $\mathrm{Ca}, \mathrm{Fe}, \mathrm{Mg}$, and $\mathrm{K}$ levels in serum of Wistar albino male rats exposed to Cd. Environmental Science and Pollution Research, 27: 7702-7711.

[43] Türkez H., Geyikoglu F., Tatar A., Keleş S., Özkan A. 2007. Effects of some boron compounds on peripheral human blood. Z Naturforsch, 62: 889-896.

[44] Bukowska B., Kowalska S. 2004. Phenol and cathechol induce prehemolytic and hemolytic changes in human erythrocytes. Toxicol Letter, 152: 73-84.

[45] Tapiero H., Townsend D.M., Tew K.D. 2004. The role of carotenoids in the prevention of human pathologies. Biomedicine Pharmacotherapy, 58: 100-110.

[46] Kakarla P., Vadluri G., Reddy K.S. 2005. Response of hepatic antioxidant system to exercise training in aging female rat. Journal of Experimental Zoology Part A Comperative Experimental Biology, 303: 203-208. 
[47] Afaq F., Abidi P., Matin R., Rahman Q. 1998. Activation of alveolar macrophages and peripheral red blood cells in rats exposed to fibers/particles. Toxicol Letter, 99: 175-182.

[48] Prasad N.R., Srinivasan M., Pugalendi K.V., Menon V.P. 2006. Protective effect of ferulic acid on gamma-radiation-induced micronuclei, dicentric aberration and lipid peroxidation in human lymphocytes. Mutation Research, 603: 129-134.

[49] Hunt C.D., Idso J.P. 1999. Dietary boron as a physiological regulator of the normal inflammatory response: a review and current research progress. The Journal of Trace Elements in Experimental Medicine, 12: 221-233.

[50] Kucukkurt I., Ince S., Demirel H.H., Turkmen R., Akbel E., Celik Y. 2015. The Effects of Boron on Arsenic-Induced Lipid Peroxidation and Antioxidant Status in Male and Female Rats. Journal of Biochemical and Molecular Toxicology, DOI: 10.1002/jbt.21729.

[51] Barr R.D., Barton S.A., Schull W.J. 1996. Boron levels in man: preliminary evidence of genetic regulation and some implications for human biology. Medical Hypotheses, 46: 286-289.

[52] Hall I..H, Starnes C.O., McPhail A.T., Wisian-Neilson P., Das M. K., Harchelroad F. Jr, Spielvogel B.F. 1980. Anti-inflammatory activity of amine cyanoboranes, amine carboxyboranes, and related compounds. Journal of Pharmaceutical Science, 69: 1025-1029.

[53] Sugino N., Karube-Harada A., Sakata A., Takiguchi S., Kato H. 2002. Different mechanisms for the induction of copper-zinc superoxide dismutase and manganase superoxide dismutase by progesterone in human endometrial stromal cells. Human Reproduction, 17: 1709-1714.

[54] Tung B.T., Rodriguez-Bies E., Thanh H.N., Le-Thi-Thu H., Navas P., Sanchez V.M., LópezLluch G. 2015. Organ and tissue-dependent effect of resveratrol and exercise on antioxidant defenses of old mice. Aging Clinical and Experimental Research, DOI: 10.1007/s40520-4001540366-40528.

[55] Kashiwagi A., Kashiwagi K., Takase M., Hanada H., Nakamura M. 1997. Comparison of catalase in diploid and haploid Rana rugosa using heat and chemical inactivation techniques. Comperative Biochemistry Physiology B Biochemistry and Molecular Biology, 118: 499-503.

[56] Goyal M.M., Basak A. 2010. Human catalase: looking for complete identity. Protein Cell, 1: 888897.

[57] Nicholls P. 2012. Classical catalase: ancient and modern. Archives of Biochemistry and Biophysics, 525: 95-101.

[58] Verbitskaya G.V. 1975. Experimental and field investigations concerning the hygienicevaluation of boron-containing drinking water. Gig i Sanit, 7: 49-53.

[59] Hunt C.D., Herbel J.L., Idso J.P. 1993. Dietary boron modifies the effects of execise training on bone and energy substrate metabolism in the rat. FASEB J, 7: A204

[60] Türkez H. 2007. Bazı Bor Bileşiklerinin İn vitro Şartlarda Periferal İnsan Kanı Üzerine Genetik ve Biyokimyasal Etkileri. Doktora Tezi, Atatürk Üniversitesi, Fen Bilimleri Enstitüsü, Erzurum.

[61] Tate D.J., Newsome D.A. 2006. A novel zinc compound (zinc monocysteine) enhances the antioxidant capacity of human retinal pigment epithelial cells. Current Eye Research, 31: 675683.

[62] Kurtoğlu F., Kurtoglu V., Celik I., Kececi T., Nizamlioglu M. 2005. Effects of dietary boron supplementation on some biochemical parameters, peripheral blood lymphocytes, splenic plasma cells and bone characteristics of broiler chicks given diets with adequate or inadequate cholecalciferol (vitamin D3) content. British Poultry Science, 46: 87-96.

[63] Ince S., Kucukkurt I., Demirel H.H., Acaroz D.A., Akbel E., Cigerci I.H. 2014. Protective effects of boron on cyclophosphamide induced lipid peroxidation and genotoxicity in rats. Chemosphere, 108: 197-204.

[64] Liu C.X., Jiang L.Y., Wang H., Guo Z.H., Cai X.X. 2007. A novel disposable amperometric biosensor based on trienzyme electrode for the determination of total creatinine kinase. Sensors and Actuators B Chemical, 122: 295-300.

[65] Moreira F.T.C., Dutra R.A.F., Noronha J.P., Sales M.G.F. 2014. Novel sensory surface for Creatine Kinase electrochemical detection. Biosensors and Bioelectronics, 56: 217-222.

[66] Eren M., Uyanık F., Güçlü B.K., Atasever A. 2012. The influence of dietary boron supplementation on performance some biochemical parameters and organs in broilers. Asian Journal of Veterinary Advances, 7: 1079-1089. 
[67] Tagawa T., Kono K., Dote T., Usuda K., Nishiura H., Koizumi C., Saito M., Nakaya H., Nagaie H. 2000. Pharmacokinetics and effects after intravenous administration of high-dose boron to rat. International Archives of Occupational Environmental Health, 73: 98-100. 